\title{
SYNTHESIS OF LIQUID ORGANIC FERTILIZER BASED ON CHICKEN MANURE USING BIOSCA AND FUNGUS BIOACTIVATOR Trichoderma harzianum
}

\author{
Rahmad $^{1 *}$, Abd. Karim ${ }^{1}$, Nursiah La Nafie ${ }^{1}$, Muh. Jayadi ${ }^{2}$ \\ ${ }^{1}$ Department of Chemistry, Faculty of Mathematics and Natural Sciences, Hasanuddin University, \\ Perintis Kemerdekaan Street KM 10, Tamalanrea Makasssar, Indonesia 90245 \\ ${ }^{2}$ Department of Agrotechnology, Faculty of Agriculture, Hasanuddin University, Perintis Kemerdekaan \\ Street KM 10, Tamalanrea Makasssar, Indonesia 90245 \\ *Corresponding author: rahmadkimia0@gmail.com
}

\begin{abstract}
Abstrak. Pembuatan pupuk organik cair dari bahan dasar kotoran ayam dengan penambahan bioaktivator Biosca dan jamur Trichoderma harzianum bertujuan untuk menentukan pengaruh waktu pembuatan terhadap $\mathrm{pH}$ dan unsur makro $(\mathrm{N}$, $\mathrm{P}$, dan $\mathrm{K}$ ), menganalisis pengaruh dan menentukan komposisi bioaktivator terhadap $\mathrm{pH}$, kandungan unsur makro dan pertumbuhan serta produksi tanaman tomat. Metode pembuatan pupuk organik cair ini yaitu kotoran ayam dilarutkan menggunakan air di dalam tong komposter, kemudian dilakukan pengomposan dengan penambahan bioaktivator yang terdiri atas B1 (40 mL Biosca), B2 (40 mL T. harzianum), B3 (10 mL Biosca $+30 \mathrm{~mL}$ T. harzianum), B4 (20 mL Biosca $+20 \mathrm{~mL}$ T. harzianum) dan B5 (30 $\mathrm{mL}$ Biosca $+10 \mathrm{~mL}$ T. harzianum). Pengomposan dilakukan dengan variasi waktu 7 hari (M1), 14 hari (M2) dan 21 hari (M3). Hasil peneltian menunjukkan bahwa proses pembuatan pupuk organik cair dengan variasi waktu pengomposan dan komposisi bioaktivator yang efektif dalam meningkatkan kadar unsur makro serta $\mathrm{pH}$ yang baik adalah B5 dengan waktu pengomposan 21 hari. Pengaruh komposisi bioaktivator tersebut terhadap indikator nilai $\mathrm{pH}$ dan unsur makro yaitu dengan nilai kadar N: 5,33\%, kadar P: 2,41\%, kadar K: 1,34\% pada pH: 7,1. Sedangkan pengaruh terhadap tanaman tomat pada pengamatan minggu ke 10 yaitu untuk pertumbuhan tinggi tanaman: $197,7 \mathrm{~cm}$, rata-rata diameter tanaman: $16,27 \mathrm{~mm}$, rata-rata daun yang dihasilkan: 41 lembar, serta untuk produksi rata-rata jumlah buah: 32 buah, rata-rata berat buah: $32,4 \mathrm{~g}$.
\end{abstract}

Kata Kunci: pupuk organik cair, biosca, jamur Trichoderma harzianum, unsur hara, kotoran ayam

\begin{abstract}
Production of liquid organic fertilizer from chicken feces with addition bioaktivator Biosca and Trichoderma harzianum fungus aims to determine the influence of time against $\mathrm{pH}$ and macro elements ( $\mathrm{N}, \mathrm{P}$, and $\mathrm{K}$ ), analyze the influence and determine the bioactivator composition against $\mathrm{pH}$, macro element content, growth and production of tomato plants. The method of making this liquid organic fertilizer is chicken feces dissolved using water in a composter, then composted with addition of bioactivator which is consisting B1 (40 mL Biosca), B2 (40 mL T. harzianum), B3 (10 mL Biosca $+30 \mathrm{~mL}$ T. harzianum), B4 (20 mL Biosca +20 $\mathrm{mL} \mathrm{T.} \mathrm{harzianum})$ and $\mathrm{B} 5(30 \mathrm{~mL}$ Biosca $+10 \mathrm{~mL} \mathrm{~T}$. harzianum $)$. Composting is done by time variations of 7 days (M1), 14 days (M2) and 21 days (M3). The result of research shows that the process of making organic liquid fertilizer with time variation of composting and effective bioactivator composition in increasing macro element level and good $\mathrm{pH}$ is $\mathrm{B} 5$ with 21 days of composting time. The influence of bioactivator composition against $\mathrm{pH}$ and macro element indicator is showed by value of $\mathrm{N}: 5,33 \%, \mathrm{P}: 2,41 \%, \mathrm{~K}: 1,34 \%$ at $\mathrm{pH}: 7,1$. While the influence against tomato plants on the observation at the 10th week is for the growth of plant height: 197,7 $\mathrm{cm}$, average of plant diameter: 16,27 mm, average of leaf production: 41 sheets, and for the average of fruit production: 32 pieces, average of fruit weight: $32,4 \mathrm{~g}$.
\end{abstract}

Keywords: Liquid organic fertilizer, biosca, Trichoderma harzianum fungus, soil nutrients, chicken manure 


\section{INTRODUCTION}

Land on agricultural land, generally contains nutrients needed by plants. Nutrients are chemical compounds that support the survival of plants. These elements will be reduced because it is used by plants in the process of growth and productivity. As a result, the farmers made several efforts to restore the abundance of elements in the soil, one of which was fertilization. The use of high artificial / inorganic fertilizers creates a variety of negative impacts, both environmental and soil conditions (biological and chemical aspects). The selection of inorganic fertilizers is now considered to be less effective in restoring soil nutrients because it can damage soil conditions, especially if its use does not meet the standard of use (Irsal, 2006).

Utilization of organic waste is considered an alternative in fulfilling nutrients for plants. According to Sinaga (2009) organic waste is easily decomposed by microoganism in nature so that the impact is far safer compared to inorganic fertilizers. In other words, the risk of pollution and environmental damage is relatively small when using organic waste as a base material. The basic ingredients can come from plants and animals. Part of the material that is commonly used is the remnants that are no longer used, for example vegetable scraps, hay and livestock manure. Chicken manure is an organic waste that is widely used by farmers and farmers because it is easily processed and served on agricultural and fishery land (Yulipriyanto, 2000).
In Indonesia, chicken manure is very abundant and more dominant is not utilized. According to Yulippriyanto (2000) macromolecules contained in chicken manure waste in the form of cellulose, lignin, fat, protein, and sugar in abundant amounts. This is why chicken manure has the potential to be processed into fertilizer to restore nutrients to the soil. Dung is one example of chicken manure. The fertilizer is considered capable of providing a direct effect on the growth of plants with a certain dose. Direct administration in the form of solids on the ground is a very practical way of applying. Such methods are widely used by farmers to utilize organic chicken manure (Wahida et al., 2011).

A number of microorganisms can do this composting, such as Biosca and Trichoderma harzianum mushrooms. Biosca is a decomposer liquid containing many microorganisms that play a role in breaking down or decomposing organic waste to become fertilizer. Indriani (2004) reports that these microorganisms consist of lignolytic, cellulolytic, pretiolytic, lipolytic, aminolytic, and non-symbiotic nitrogen fixation. One study conducted by Rilawati (2009) using Biosca has been able to convert leachate wastewater (liquid piles of organic matter) into liquid organic fertilizer with a fairly good nutrient content for plants.

Marlinda (2015) explained that liquid organic fertilizer is more easily absorbed by plants and in the form of concentrate so it is more economical because it can be diluted. These fertilizers can be made in a short time 
and have good quality through the process of composting the basic ingredients that have been dissolved in water and added a number of bioactivators.

\section{MATERIAL AND METHODS Materials}

The materials used in this study were chicken manure, biosca solution, Trichorderma harzianum mushroom, buffer solution $\mathrm{pH} \mathrm{7,0}$ and $\mathrm{pH}$ 4,0, $\mathrm{H}_{2} \mathrm{SO}_{4}$ pa. $98 \%, 1 \%$ boric acid, Conway indicator, selenium mixture, $\mathrm{NaOH}$ $40 \%, \mathrm{~K}_{2} \mathrm{Cr}_{2} \mathrm{O}_{7} 1 \mathrm{~N}, 65 \%$ pa $\mathrm{HNO}_{3}$, $\mathrm{HClO}_{4}$ pa. $70 \%$, standard solution of $\mathrm{K}$ (potassium) $1000 \mathrm{ppm}$, standard solution of $\mathrm{P}$ (phosphorus) $500 \mathrm{ppm}$, ammonium heptamolibdat, potassium antimoniltartate, $\mathrm{H}_{2} \mathrm{SO}_{4}$, ascorbic acid, glacial acetic acid, $\mathrm{HCl}$, phosphate, $\mathrm{BaCl}_{2}$, aquades, and paint cans $20 \mathrm{~kg}$ used.

\section{Tools}

The tools used in this study are 50 $\mathrm{mL}$ measuring cup, spray flask, $\mathrm{pH}$ meter, analytic balance, destilator/flask kjeldahl unit, burette, erlenmeyer 100 $\mathrm{mL}$ measuring flask $50 \mathrm{~mL}, 100 \mathrm{~mL}, 10$ $\mathrm{mL}$ measuring pipette, $1 \mathrm{~mL}$ volume pipette, ruler, meter, calipers, $5 \mathrm{~mL}$, beaker, vortex mixer, spectrophotometer UV-VIS model 340 and atomic absorption spectrometer.

\section{Methods}

This research uses Factorial Completely Randomized Design method with the following treatment:

Factor I: Biosca $+T$. harzianum, with three levels of treatment

$$
\begin{aligned}
\mathrm{B} 1 & =\mathrm{Biosca}=40 \mathrm{~mL} \\
\mathrm{~B} 2 & =T \cdot \text { harzianum }=40 \mathrm{~mL} \\
\mathrm{~B} 3 & =\mathrm{Biosca}+T \cdot \text { harzianum } \\
& =(10+30) \mathrm{mL} \\
\mathrm{B} 4 & =\text { Biosca }+T . \text { harzianum } \\
& =(20+20) \mathrm{mL} \\
\mathrm{B} 5 & =\text { Biosca }+T . \text { harzianum } \\
& =(30+10) \mathrm{mL}
\end{aligned}
$$

Factor II: Composting time with three levels of treatment

$$
\begin{aligned}
& \text { M1 }=7 \text { days } \\
& \text { M2 }=14 \text { days } \\
& \text { M3 }=21 \text { days }
\end{aligned}
$$

With a combination of composting between Bioactivator (B) and composting time $(\mathrm{M})$ and $\mathrm{M} 2 \mathrm{~B} 0$ (control) as follows:

\section{B1M1 B2M1 B3M1 B4M1 B5M1 \\ B1M2 B2M2 B3M2 B4M2 B5M2 \\ B1M3 B2M3 B3M3 B4M3 B5M3}

\section{Procedures}

\section{Making Composter}

Composter barrel is made from 20 $\mathrm{kg}$ of used paint cans. The can is cleaned and dried first. The top of the can is kept open as the air in and out.

\section{Material Preparation and Content Analysis}

The basic material is chicken waste that is 1 day old, this is done to uniform $\mathrm{pH}$ and macro element content. The waste is first cleaned/sorted from mixed chicken parts such as feathers and stones which are the base where chicken manure collects and follows when taking it. Then chicken manure is made loose 
first. Clean chicken manure was analyzed for $\mathrm{pH}$ and macronic elements in accordance with the procedure in section 3.5.4 as a comparison material at the stage before composting (Sinaga, 2009).

\section{Making Organic Liquid Fertilizers}

Chicken manure is weighed as much as $10 \mathrm{~kg}$ and then put in 16 barrels of composter. Each barrel of water is added as much as $10 \mathrm{~L}$ and bioactivators based on predetermined variations. In the mixture, composting is carried out with time variations. Composting was carried out in three stages for all treatments including controls (M2B0). Composting 3 weeks of liquid organic fertilizer is carried out in the first week for up to 3 weeks. Composting of 2 weeks of liquid organic fertilizer is carried out in the second week to 2 weeks, while composting 1 week of liquid organic fertilizer is carried out for weeks 3 to 1 week (Sinaga, 2009).

\section{pH Analysis and Macro Elements} (Eviati and Sulaeman, 2009).

\section{1. pH Test}

The fertilizer is weighed as much as $10 \mathrm{~g}$, put in a shake bottle and added $50 \mathrm{~mL}$ of aquades. The solution is shaken with the machine shake for 30 minutes. Soil suspension is measured by a $\mathrm{pH}$ meter calibrated using a $\mathrm{pH} 7.0$ buffer solution and $\mathrm{pH} 4.0$.

\section{Nitrogen total $_{\text {Levels Test }}$}

\subsection{Conway Inicators}

BCG (Brom Cresol Green) weighed $0.15 \mathrm{~g}$ and added $0.1 \mathrm{~g}$ methyl red in $100 \mathrm{~mL} \mathrm{96 \%} \mathrm{ethanol} \mathrm{(Eviati} \mathrm{and}$ Sulaeman, 2009).

\subsection{Determination of $\mathrm{N}$-total}

The fertilizer is weighed $0,250 \mathrm{~g}$ and put into the kjeldahl flask. Kjedhal flask which has contained fertilizer, added 0,25-0,50 g selenium mixture and $3 \mathrm{~mL} \quad \mathrm{H}_{2} \mathrm{SO}_{4}$ pa, shaken until homogeneous and allowed to stand 2-3 hours. The mixture is completely destroyed with a gradual temperature of $150{ }^{\circ} \mathrm{C}$ until finally the max temperature is $350{ }^{\circ} \mathrm{C}$ and clear liquid is obtained (33,5 hours). The clear liquid is cooled and diluted with a little distilled water to prevent crystallization. The liquid was transferred into $250 \mathrm{~mL}$ volume distillation boiling flask, added aquades to half the volume of flask and added boiling stone. The prepared reservoir distillate consisting of a mixture of 10 $\mathrm{mL} 1 \%$ boric acid and 3 drops of the Conway indicator into an erlenmeyer volume of $100 \mathrm{~mL}$. The mixture was distilled by adding $20 \mathrm{~mL}$ of $40 \% \mathrm{NaOH}$ to the kjedhal flask. The distillation process is complete if the volume of liquid in erlenmeyer has reached around $75 \mathrm{~mL}$. The distillation results are titrated with $0,05 \mathrm{~N} \mathrm{H}_{2} \mathrm{SO}_{4}$, until the end point (the color of the solution changes from green to pink) $=\mathrm{A} \mathrm{mL}$, determination of the blank is done $=\mathrm{A} 1$ $\mathrm{mL}$. 


\subsection{K (Potassium) and P (Phosphorus)} Levels Test

\subsubsection{Making standard series solutions}

\subsubsection{K (Potassium) Standard}

The standard solution of potassium $1000 \mathrm{ppm}$ is piped as much as $0.2,0.4$, 0.8 , and $1.6 \mathrm{~mL}$ into 4 erlenmeyer volumes of $100 \mathrm{~mL}$. Each mixture was diluted with distilled water to the limit of tera. The solution is $2,4,8$ and $16 \mathrm{ppm}$ potassium

\subsubsection{P (Phosphorus) Standard}

The standard Fosfot 500 ppm solution is piped as much as $0.2,0.5,0.8$, 1.6, and 3.2 into 5 erlenmeyer volumes of $100 \mathrm{~mL}$. Each mixture was diluted with distilled water to the limit of tera. The solution is $1,2,4,8$, and 16 ppm potassium.

\subsection{Sample Preparation}

The fertilizer is weighed $0,5 \mathrm{~g}$ into the kjeldahl flask and added $5 \mathrm{~mL} \mathrm{HNO}_{3}$ and $0,5 \mathrm{~mL} \mathrm{HClO}_{4}$, then shaken and left for 24 hours. The mixture is heated in block digestor starting at a temperature of $100{ }^{\circ} \mathrm{C}$, after the yellow steam runs out the temperature is increased to $200{ }^{\circ} \mathrm{C}$. The heating process is terminated when white steam is released and the liquid in the flask remains about $0,5 \mathrm{~mL}$. The mixture is then cooled and diluted with distilled water until the volume becomes $50 \mathrm{~mL}$, shaken until homogeneous, and left for 24 hours then filtered with W-41 filter paper to obtain clear extract (extra A)

\subsection{Determination of $\mathrm{K}$ (Potassium) Levels}

2.5.1 Making a calibration curve

The standard series containing potassium with concentrations of 2, 4, 8, and $16 \mathrm{ppm}$ from the mother liquor 1000 ppm $\mathrm{K}$ was measured and recorded absorbance using an atomic absorption spectrometer. The data obtained is made a calibration curve between concentration (x) and absorbance (y) (Norma et al, 2014).

\subsubsection{Determination of $\mathrm{K}$ (Potassium) Levels}

A extract piped $1 \mathrm{~mL}$ into a chemical tube volume of $20 \mathrm{~mL}$, added 9 $\mathrm{mL}$ of distilled water, then shaken with a vortex mixer until homogeneous. This extract is a 10x dilution (extract $\mathrm{B}$ ). The mixture is measured absorbance using an atomic absorption spectrometer. By using a calibration curve made from a standard series, the mixture is determined by its concentration using equation (1):

$$
\mathrm{Y}=\mathrm{bx}+\mathrm{a}
$$

Information:

$\mathrm{Y}$ : Sample absorbance

$\mathrm{b}$ : slope

$\mathrm{a}:$ intercept

$\mathrm{x}$ : Sample levels (ppm)

\subsection{Determination of $\mathbf{P}$ (Phosphorus) Levels}

2.6.1 Making P-determination color generator reagents (Phosphates)

Concentrated Reagent: $12 \mathrm{~g}$ of ammonium heptamolibdat plus 0,275 grams of potassium antimoniltartate plus $140 \mathrm{ml}$ of $\mathrm{H}_{2} \mathrm{SO}_{4}$ in $1000 \mathrm{~mL}$ of aquades 
Dilute Reagent: (made when it will be used) $0,53 \mathrm{~g}$ of ascorbic acid plus $50 \mathrm{~mL}$ of concentrated reagent in $500 \mathrm{~mL}$ of aquades.

\subsubsection{Making Calibration Curve}

Standard solutions 1, 2, 4, 8 and 16 ppm phosphate piped $1 \mathrm{~mL}$ into 6 chemical tubes of $20 \mathrm{~mL}, 9 \mathrm{~mL}$ of each Phosphate-determination generator color reactor were added respectively. All mixtures are homogenized with vortex mixer, then allowed to stand for 15-25 minutes, then measured the absorbance with a visible spectrophotometer at a wavelength of $889 \mathrm{~nm}$. The resulting data is made a standard solution calibration curve between absorbance (y) and concentration (x) (Norma et al, 2014).

\subsubsection{Determination of $P$ (Phosphorus) Levels}

Sample B extract was piped $1 \mathrm{~mL}$ into a chemical tube volume of $20 \mathrm{~mL}$ (pipetted before measurement $\mathrm{K}$ ). B extract is added $9 \mathrm{~mL}$ of color generator reagent, then shaken with a vortex mixer until homogeneous. The mixture was left to stand for 15-25 minutes, then the absorbance was obtained with a UV-VIS spectrophotometer at a wavelength of $889 \mathrm{~nm}$ and the concentration was determined using equation (2) resulting from the standard series calibration curve:

$$
\mathrm{Y}=\mathrm{bx}+\mathrm{a}
$$

Information:

$$
\begin{aligned}
& \mathrm{Y}: \text { Sample absorbance } \\
& \mathrm{b}: \text { slope } \\
& \mathrm{a}: \text { intercept } \\
& \mathrm{x}: \text { Sample levels (ppm) }
\end{aligned}
$$

\section{Application of Organic Liquid Fertilizers to Tomato Plants (Karina)}

Polybags are prepared with a large size that contains $10 \mathrm{~kg}$ of soil growing media Grumusol. The nursery is carried out first by means of sprinkling, for sprinkling tomato seeds in a polybag measuring $30 \times 30 \mathrm{~cm} \times 0.07 \mathrm{~mm}$ which has been given a planting medium. The nursery media is the same as the planting media, namely Grumusol soil. Each polybag sown 3 tomato seeds. After the seedlings grow, which is one week after the seedlings, a week later the seeds are transferred to a larger polybag to do thinning, each polybag is planted with 1 seed. The seeds are transferred to the planting medium which is best at the age of seedlings 3-7 days after seeding. The seeds planted are selected for uniform growth. The liquid organic fertilizer produced, mixed with water with a ratio of 1: 5, then poured directly on the planting medium each of $\pm 370 \mathrm{~mL}$ with the rule of treatment once a week. The parameters in this application are growth and fruit production (Setoadji, 2016)

\section{RESULTS AND DISCUSSION}

\section{Analysis of Macro elements and pH on basic materials}

The basic ingredients in the form of chicken manure are analyzed by $\mathrm{pH}$ and macro elements before composting. This is done to find out the changes that occur after the base material has undergone a decomposition process. Analysis of $\mathrm{pH}$ and macro elements of liquid organic fertilizer can be seen in Table 3. 
Table 3. Results of Analysis of Macro Elemental Content and $\mathrm{pH}$ of Basic Materials

\begin{tabular}{clc}
\hline NO & $\begin{array}{l}\text { Chemical } \\
\text { Analysis }\end{array}$ & $\begin{array}{c}\text { Basic Material } \\
\text { (Chicken } \\
\text { Manure) }\end{array}$ \\
\hline 1 & $\mathrm{pH} \quad 6,7$ \\
\hline 2 & $\begin{array}{l}\mathrm{N}_{\text {total Levels }} \\
\left.\text { Nitrogen }_{\text {total }}\right) \\
(\%)\end{array}$ & 0,16 \\
\hline 3 & $\begin{array}{l}\mathrm{P} \text { (Phosphrus) } \\
\text { Levels (\%) }\end{array}$ & 0,12 \\
\hline 4 & $\begin{array}{l}\text { K (Potassium) } \\
\text { Levels (\%) }\end{array}$ & 0,16 \\
\hline
\end{tabular}

Table 3 shows that the nutrients of basic ingredients are very far from the minimum requirements of liquid organic fertilizer, the $\mathrm{pH}$ value and the level of macro elements cannot be used directly as a nutrient supplier for plants. The nutrients needed by plants are mostly still in the form of macromolecules such as cellulose, lignin, fat and sugar (Yulipryanto, 2000). Chicken manure as a liquid organic fertilizer material will experience decomposition with a long duration of time (Yulipryanto, 2000).

\section{Decomposition of Materials and} Quality of Liquid Organic Fertilizers

Composting is done so that the decomposition of macromolecules into simpler compounds in organic waste occurs. When immersing organic materials in making liquid compost there are several chemical changes carried out by microorganisms. Important chemical changes are as follows, namely decomposition of carbohydrates, cellulose, and hemicellulose, decomposition of fat substances into $\mathrm{CO}_{2}$ and water, an increase in several types of nutrients from the body of microorganisms, especially nitrogen $(\mathrm{N})$, phosphorus $(\mathrm{P})$, and potassium $(\mathrm{K})$. These elements will be released again if the microorganism dies, releasing nutrients from organic compounds into inorganic compounds that are useful for plants (Sinaga, 2009).

\subsection{Changes in $\mathrm{pH}$ during composting of basic ingredients}

Organic acids will be formed at the beginning of the composting process. This condition will encourage fungal growth and decompose lignin and cellulose in the base material (Chalimatus, 2013). Changes in $\mathrm{pH}$ values that occur in basic materials that experience the usual decomposition from low to high and experience a reduction in return, or in other words from acidic conditions to bases and return to neutral (Fitria, 2008). The observations of changes in $\mathrm{pH}$ of liquid organic fertilizer samples during composting can be seen in Figure 2.

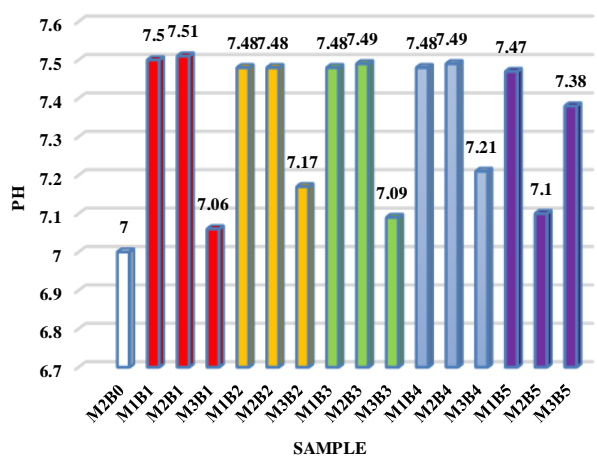

Figure. 2 Histograms Changes in $\mathrm{pH}$ of POC during Composting

Based on the data obtained, the presence of bioactivators greatly affects the $\mathrm{pH}$ value. The $\mathrm{pH}$ of the base material is 6,7 (acidic conditions). According to Fitria (2008) in neutral pH 
conditions it will not cause problems in microorganism activity. In general, microorganisms can only live in a neutral atmosphere. If there is no activity of microorganisms, the decomposition process does not take place and results in the availability of nutrients. In other words, $\mathrm{pH}$ can indicate the availability of nutrients both in soil and fertilizer. The M2B0 sample has a $\mathrm{pH}$ value of 7 which is most effective for the POC standard. However, this sample does not contain bioactivators at all. So it can be concluded that if the basic materials are composted without the addition of bioactivators, the $\mathrm{pH}$ will experience a good increase to allow the POC to be absorbed by the plant. In terms of comparing samples containing bioactivators, it will refer to the data of the last week, where the activity of microorganisms has decreased and the $\mathrm{pH}$ value has not changed again. The most effective sample of M3B1 with a $\mathrm{pH}$ value approaching neutral is 7,06 .

There is a slight deviation in the data in sample B5 when compared to the pattern of changes from each sample. In the final week of composting, the results of the POC with B5 bioactivator composition experienced an increase in $\mathrm{pH}$ value. Fitria (2008) explains that a decrease in $\mathrm{pH}$ value is caused by the activity of breaking acidic bacteria macromolecular materials such as carbohydrates, proteins and lignin which produce organic acids such as acetic acid and pyruvic acid which then causes the $\mathrm{pH}$ value in $\mathrm{POC}$ to decrease. While the increase in $\mathrm{pH}$ value is caused by the activity of nitrogen fixing microorganisms that will produce ammonia compounds. If based on the description above, it can be concluded that the concentration of $T$. harzianum added to the composition of B5 is not so optimal that a number of microorganisms such as nitrogen-fixing microorganisms are active after the death of pathogenic bacteria.

\subsection{Quality of Liquid Organic Fertilizer}

\subsection{1 $\mathrm{N}_{\text {total }}\left(\right.$ Nitrogen $\left._{\text {total }}\right)$ Levels}

Nitrogen $(\mathrm{N})$ is one of the elements needed by plants for vegetative growth and protein formation, if plants lack nitrogen will cause plants to become stunted, root growth is limited, and leaves become yellow and deciduous (Ruhnayat, 2007). Determination of Ntotal content is done by kjeldahl method. Samples through 3 steps of treatment, destined, distillation with bases and titrated. Base material nitrogen content is $0.16 \%$. This value is still low and cannot be used directly on plants, while the requirement for nitrogen levels in fertilizers is a minimum of 3\%. Graph of $\mathrm{N}_{\text {total }}$ liquid organic fertilizer produced can be seen in Figure 3.

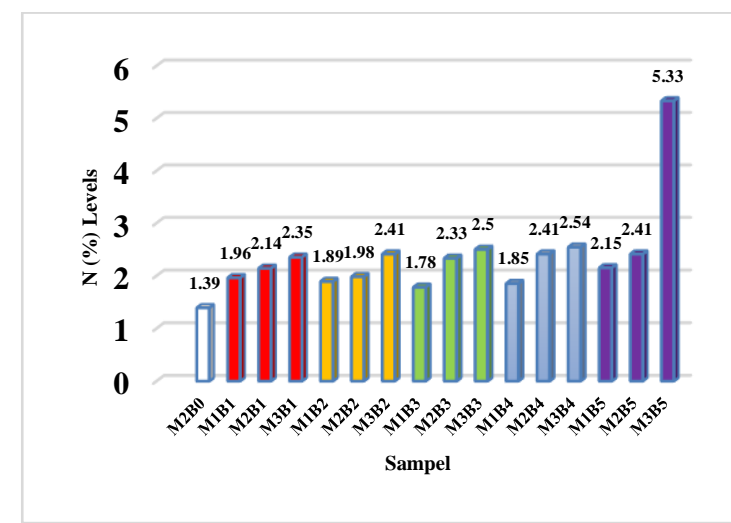

Figure 3. $\mathrm{N}_{\text {total }}\left(\right.$ Nitrogen $\left._{\text {total }}\right)$ Graphs Level in POC 
The data shows the value of $\mathrm{N}$ content that meets the standard, namely the M3B5 sample with Nitrogen level of $5,33 \%$, while the POC sample which has the lowest value is M2B0 with nitrogen level of $1,39 \%$. This shows that the overhaul of nitrogen in the base material is strongly influenced by the presence of bioactivators when compared to not added at all. Nitrogen-fixing bacteria in the form of Actinomycetes will accumulate nitrogen in the body after decomposing from organic materials that are rich in nitrogen such as proteins (Widawati, 2010)

In addition to the activity of microorganisms, which need to be considered is the basic materials because it will be used as the main material of microorganisms in the metabolism of his life. So, it is important to add other material to the base material to optimize the energy source of decomposing microorganisms such as bran (Fitria, 2008). The effective bioactivator composition is used in composting for nitrogen reshuffle in the base material namely B5 consisting of a mixture of Biosca $+T$. harzianum $30 \mathrm{~mL}+10 \mathrm{~mL}$ each. Not so maximal reshuffle occurs if the bioactivator only contains Biosca (M3B1). Maspary (2011) explains the existence of $T$. harzianum as a fungicide in nature. Trichoderma harzianum supports the reshaping of microorganisms found in biosca by suppressing the growth of pathogenic fungi on the base material.

Nitrogen levels increase from the first week to week 3 . The pattern is shown in almost all treatments. So it was concluded that the duration of composting for nitrogen reformation in the base material is for 3 weeks.

\subsubsection{P (Phosphorus) Levels}

Phosphorus (P) is used for growth for plants and is converted into humus by plants and makes the soil fertile. Phosphorus is measured by the UV-VIS spectrophotometer model 340. The sample is made into a complex compound (blue) by adding ammonium heptamolibdat in an acidic atmosphere. The $\mathrm{P}$ level (measured in the form of $\mathrm{P}$ 2OO5) the liquid organic fertilizer produced can be seen in Figure 4.

The basic phosphorus level is $0,12 \%$, this value is still far from the requirement that the $\mathrm{P}$ level in the minimum fertilizer is $3 \%$. The data shows that there is no $\mathrm{P}$ value that meets the minimum standard, but the one approaching the minimum POC requirement is $\mathrm{M} 3 \mathrm{~B} 2$ with $\mathrm{P} 2 \mathrm{O} 5$ level of $2,63 \%$, while the POC sample which has the lowest value is $\mathrm{M} 2 \mathrm{~B} 0$ with nitrogen level of $1.19 \%$.

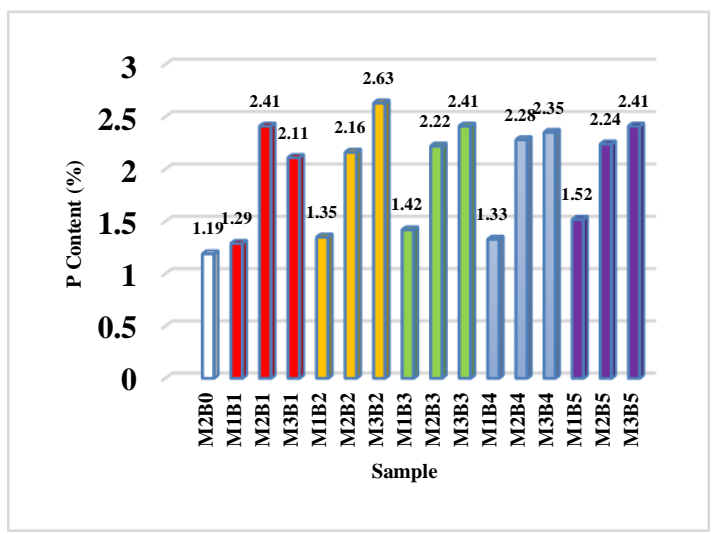

Figure. 4 P (Phosphorus) Levels in POC

From this data also shows that there is a considerable difference between samples using bioactivators and without bioactivators. The phosphorus overhaul 
in the base material is strongly influenced by the presence of bioactivators with certain compositions when compared to not added at all. The bioactivator composition that was effectively used in composting for the overhaul of Nitrogen in the base material was B2 containing $40 \mathrm{~mL}$ of $\mathrm{T}$. harzianum with the highest $\mathrm{P}$ level of $2,63 \%$. This value is not much different from the maximum value of each other bioactivator composition which is $2,41 \%$ for B1, B3 and B5. The value of these levels can be increased by adding other organic materials which are rich in $\mathrm{P}$ levels. It is suggested that in the next study, this can further optimize the levels of $\mathrm{P}$ organic liquid fertilizer produced (Fitria, 2008).

In principle, composting breaks down macromolecular compounds into simple compounds needed by plants (Murbondo in Sinaga, 2009). These nutrients will continue to increase in level as long as the composting time. However, it can be seen in the data that it deviates slightly from the principle of composting. Samples of liquid organic fertilizer with bioactivator composition B1 (40 mL Biosca) decreased in levels in the last week. Bioactivators added to the base material have the same composition for each duration of composting, so that is less likely to be one of the data deviation factors. The basic materials have different potential materials after transferring chicken manure from the farm. The basic material is chicken waste that is 1 day old. The basic materials which are contaminated with chicken manure that are more than 1 day old will have a slightly increased nutrient content from the actual value, due to the activity of microorganisms innate in the base material. Based on this description, the macromolecular decomposition process has occurred before bioactivators are added. The basic material which decomposes first will contribute excess nutrient content than desired, as seen in the $\mathrm{P}$ level for M2B1 treated liquid organic fertilizer. While the effective duration of composting is for 3 weeks.

\subsubsection{K (Potassium) Levels.}

Potassium (K) for plants functions to form proteins and carbohydrates, hardening parts of wood, increasing plant resistance to disease and increasing the quality of seeds and fruit. Kelements are widely found in young tissues (Mulyadi in Fitria, 2008). The level of K (measured in $\mathrm{K} \neg \mathrm{OO}$ ) is determined using SSA. Requirements for the content of $K$ in a minimum of $3-6 \%$ liquid organic fertilizer. The $\mathrm{K}$ content of the base material is $0,16 \%$. The research data as shown in Figure 4 shows that there is no $\mathrm{K}$ level value that meets the minimum standard, but the approach is the M3B5 sample with $\mathrm{K}$ content of $1,34 \%$, while the POC sample which has the lowest value is M2B0 with $\mathrm{K}$ level of $0,6 \%$.

The differences shown in the data, it can be concluded that the overhaul of $\mathrm{K}$ in the base material is greatly influenced by the presence of bioactivators with certain compositions when compared to not added at all.

A good bioactivator composition is used in composting for $\mathrm{K}$ reformation in the base material namely B5 consisting of a mixture of Biosca $+T$. 
harzianum $30 \mathrm{~mL}+10 \mathrm{~mL}$ each with a grade value of $1.34 \%$. This value is still below the POC minimum standard. The value of these levels can be increased by adding other organic materials which are rich in $\mathrm{K}$ content. It is suggested in future studies that this can further optimize the levels of $\mathrm{P}$ organic liquid fertilizer produced (Fitria, 2008).

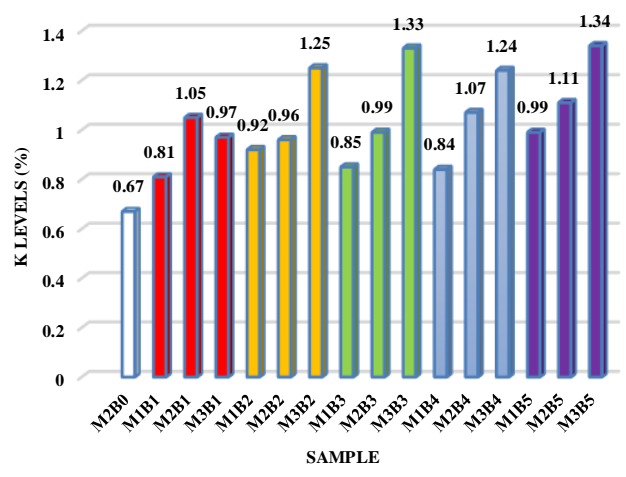

Figure 5. K(Potassium) Level in POC

Based on the data obtained, a notso-maximum reshuffle occurs if the bioactivator only contains biosca, this can be observed at the highest levels of POC samples with the composition of bioactivator B1. Maspary (2011) explains the existence of $T$. harzianum as a fungicide in nature. Tricoderma harzianum supports the reshuffle carried out by a number of microorganisms in biosca.

\subsection{Effect of Liquid Organic Fertilizer on Tomato Plants (Karina)}

The selected test plants were the Karina variety tomato plants. Indicators observed at the testing stage are growth and production. Observations begin when plants are transferred into polybags.

\subsubsection{Vegetative Growth of Tomato Plants (Karina)}

\subsubsection{Plant Height}

To find out the vegetative growth of tomato plants that were tested, observations of plant height were carried out once a week starting at the age of 1 week after transferring the seeds to the open land until harvest. Data retrieval is done by calculating the height of tomato plants from the bottom of the soil (the exact appearance of the stem) to the point where the tomato plant grows (shoots). The tool used is the ruler and meter. This study uses only 1 (one) variety of varieties, namely Karina with trees classified as determinate as high as $200 \mathrm{~cm}$. The observation of the height of tomato stems (Karina) for each treatment can be observed in the graph of tomato plant height (Karina) can be seen in Figure 6.

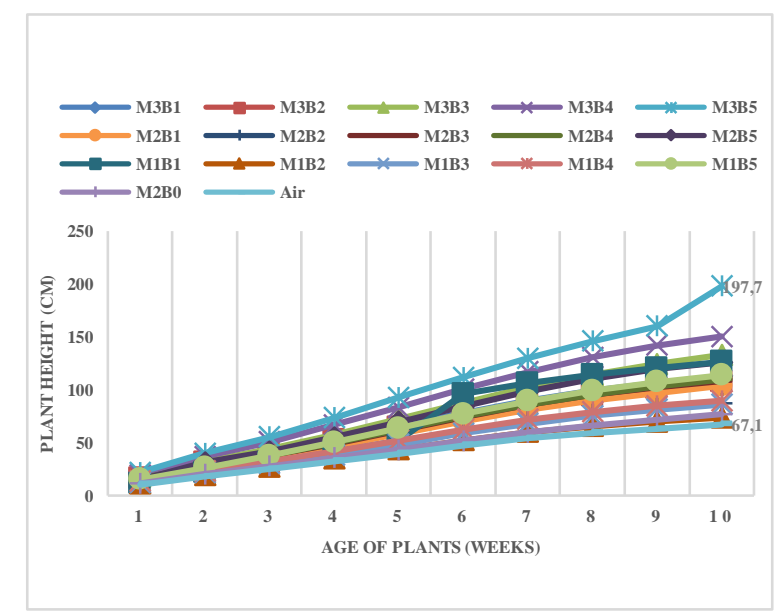

Figure 6. Height graph of tomato

From the observation data it can be seen that the plant height for all treatments at the end of the observation ranged from $67,1 \mathrm{~cm}$ to $197,7 \mathrm{~cm}$. The lowest value of plant height $(67,1 \mathrm{~cm})$ is found in the water treatment, while the highest value is in the treatment of 
M3B5. N elements play a role in the formation of plant cells, tissues and organs of plants. Nitrogen has a function as a synthesis of chlorophyll, proteins and amino acids. Therefore, plant height is strongly influenced by the presence of $\mathrm{N}$ elements in the soil at the beginning of vegetative growth (Fitria, 2008). The content of $\mathrm{N}$ elements used for all treatments ranged from 1,39 to 5,33\%.

Most of the treatments experienced rapid high growth from week 1 to week 8 and tended to be constant from week 8 to week 10 . When plants are in the vegeative growth phase, all photosynthesis results are used for vegetative growth both in high growth plants, number and size of leaves, and root growth. After the plant enters the generative phase, the result of photosynthesis most are used for the formation of flowers, fruits, and seeds and for fruit growth until they reach the cooking phase. In all treatments, at week 8 to week 10 most of the photosynthesis results have been used for fruit growth up to cooking so that the growth of plant height tends to be constant. However, from the data in figure 5 it can be observed that the M3B5 treatment tends to still experience very large growth. This is due to the large amount of $\mathrm{N}$ in the treatment, which disrupts plant productivity. This will then be explained in the production section.

\subsubsection{Stem Diameter}

The second indicator of vegetative growth is the average stem diameter. In this study, the effect of liquid organic fertilizer was observed on the growth of stem diameter of tomato plants. The measurement of stem diameter uses a tool in the form of a sliding push which is done once a week. The results of observations of tomato stem diameter (Karina) can be seen in the graph of the stem diameter of tomato plants can be seen in Figure 7.

As in the previous discussion on the observation of stem height, $\mathrm{N}$ elements play a role in overall plant growth, especially in the vegetative phase. Stem growth is still classified as vegetative growth in plants. Lack of $\mathrm{N}$ elements will result in slow plant growth, without exception to the stem part of the plant (Ruhnayat, 2007)

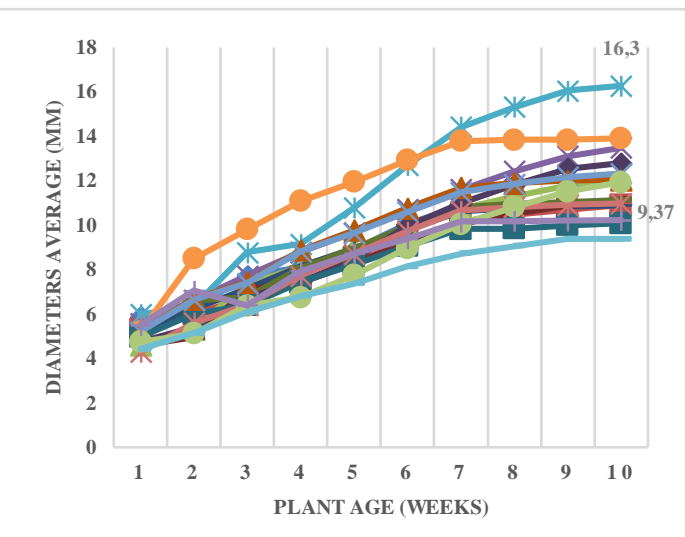

Figure 7. Average Graph Diameter of tomato plant stems (Karina)

From the data obtained, it can be seen that the average stem diameter is lowest in tomato plants treated with water with a value of $9,37 \mathrm{~mm}$, while the highest value is in tomato plants treated with M3B5 which is $16.3 \mathrm{~mm}$. The effect of the use of liquid organic fertilizer on plants is very real when viewed on the average difference in plant stem diameter at week 10 with M3B5 and water treatment $(6,89 \mathrm{~mm})$. While the influence of bioactivator use on liquid organic fertilizer on the growth of stem 
diameter can be seen by comparing the data at week 10 of the plants treated with M2B0 (10,22 mm) and M3B5. The difference between the two data still shows a significant difference for the stem diameter indicator (the average difference in stem diameter: 6,04 $\mathrm{mm}$ ). Growth of stem diameter for each treatment showed a significant increase in value from week 1 to week 8 . Then growth began to stagnate from week 8 to week 10.

\subsubsection{Leaves Quantity}

Observation of the third vegetative growth indicator is the number of leaves. Nutrient abundance also has a very synergistic relationship with the number of leaves produced by a plant. The formation of cells, tissues and organs of plants goes well, can also be seen in the number of leaves produced. In this study, observing the number of leaves is done once a week, starting from week 1 after the transfer of seeds to harvest. The results of the observation of the number of tomato leaves (Karina) produced can be seen in the graph of the average number of leaves of tomato plants can be seen in Figure 8.

From the data, it can be seen that the effect of each treatment on leaf production shows significant differences. This can be seen by looking at the difference in data at week 10 for water treatment/control (lowest average number of leaves: 24,7 sheets) and treatment of M3B4 (highest average number of leaves: 42 sheets). For some treatments a significant increase can be observed starting from week 1 to week 8 .

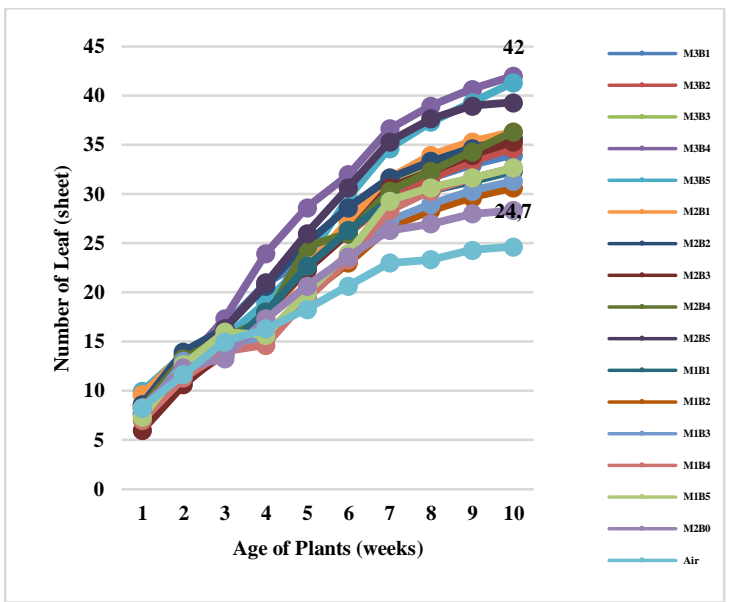

Figure 8. Graph of Average Amount of Tomato Leaves (Karina)

Nitrogen in plants plays a role as forming various compounds such as amino acids, proteins, nuclei or nuleat acids (DNA and RNA) and chlorophyll. The lack of this element causes the plant to experience chlorloris (pale green to yellow) on old leaves, stunted growth (dwarf) and necrosis (Sitompul, 2015). The highest $\mathrm{N}$ content in organic fertilizer was in the treatment of M3B5 $(5,33 \%)$, but the average number of leaves produced was not treated with M3B5 which had the highest average number of leaves but M3B4. The difference in number of leaves from the two treatments was not very large $(0,67$ sheets). An error may occur when retrieving data. In the 10th week it has entered the rainy season.

\subsubsection{Generative Effects of Tomato Plants (Karina)}

\subsubsection{Average Fruit Production}

To find out the crop production, the number of fruit was observed for all treatments. Observation of the number of fruit is done every time the harvest. In this study limited to 5 harvests. 
Observation of the number of fruits focused on 5 away for each tomato plant. The results of the observation of the number of tomatoes (Karina) produced can be seen in the graph of the average number of fruits can be seen in Figure 9.

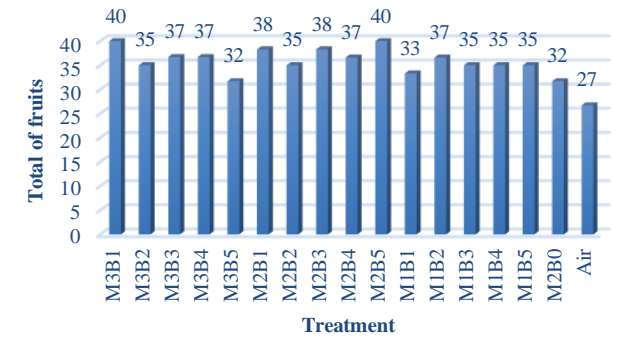

Figure 9. Graph of Average Amount of Tomatoes (Karina)

The formation of fruit in plants is inseparable from the role of elements of phosphorus (P) and Potassium (K). Phosphorus nutrients play a role in accelerating flowering and fertilization of plants and accelerating the ripening of seeds and fruit. While nutrient $\mathrm{K}$ plays a role in helping proteins, carbohydrates and sugars, helps transport sugar from leaves to fruit, strengthens plant tissues, and increases resistance to disease (Fitria, 2008). The average difference in the number of fruits produced is so evident between plants given organic fertilizer and plants that are only given water. M2B0 (average fruit production: 32 ) is a liquid organic fertilizer produced with nutrients that are still relatively low when seen in the previous discussion, but the fruit produced is more than plants that are only given water (average fruit production: 27 ) If a comparison of the number of fruits produced between M2B0 treatments that were not given bioactovators and M3B1 (40 mL Biosca) given a number of fruits bioactivator sequentially 31,7 fruits and 40 fruits, we can conclude that the effect of giving bioactivator into chicken manure so much difference.

Factors that support crop production are elements $\mathrm{P}$ and $\mathrm{K}$. In theory, plants that get good $\mathrm{P}$ and $\mathrm{K}$ stretch will produce high quality fruit. However, the average fruit produced mostly from plants fertilized with M1B1 treatment (P elemental level: 1,29\% and K elemental level: 0,81\%) and M3B1 (P elemental level: $2,11 \%$ and elemental level K: 0,97\%) with an average number of 40 fruits, while plants fertilized with M3B2 treatment (elemental level P: $2,63 \%$ and elemental level K: 1,25\%) produce a smaller average fruit 35 pieces. Data deviations are many factors that cause it, including climate conditions and pests in the form of fruit caterpillars that do not support when the plant enters the fruiting phase. For example, tomato plants that enter the fruiting phase during the rainy season, will experience a lot of flower loss. This will affect the production value of tomato plants.

\subsubsection{Fruit Weight Produced}

Fruit weight is an indicator of crop production after the amount of fruit produced. The fruits harvested from away 1 to away 5 for all treatments on tomato plants were measured for each weight. The results of the observation of the average weight of tomatoes (Karina) produced can be seen in the graph of the average fruit weight produced can be seen in Figure 10. 


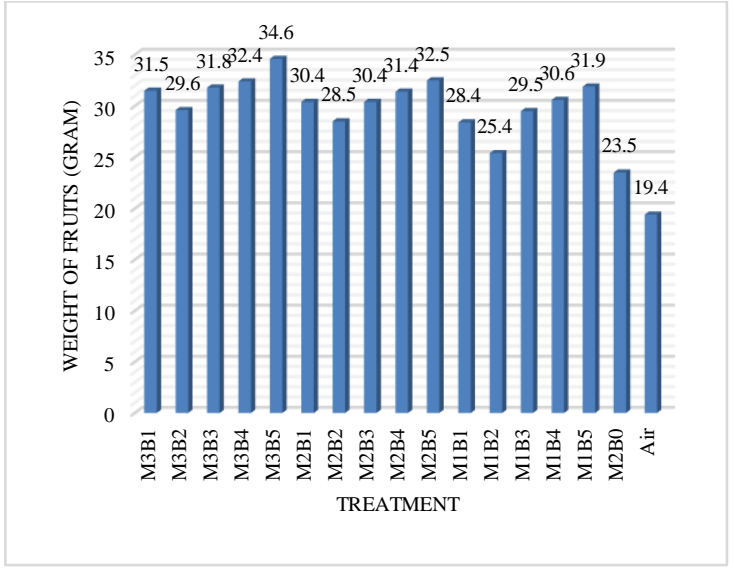

Figure 10. Average Graph of Amount of Tomato Leaves (Karina)

The highest fruit weight was obtained by plants treated with M3B5 with a value of 34,6 grams, while the lowest fruit weight value was found in water treatment plants, namely 19,4 grams. From this data it can be concluded that the effect of giving liquid organic fertilizer is very real by looking at the weight difference produced. Then the difference in fruit weight between the M2B0 treatment with liquid organic fertilizer given a number of bioactivators showed that the administration of bioactivators was quite effective in making the quality of the fruit increase. Especially if the difference between M2B0 and M3B5 is compared, the weight of the fruit produced is very large (11,1 grams).

Research with the same topic was conducted before showing a harmonious relationship between tomato plants that produce the most fruit and tomatoes which have the highest fruit weight value (Sinaga, 2009). However, the data obtained shows that this is not the case. Tomato plants with M3B5 treatment had the highest fruit weight value $(34,6$ grams) compared to tomato plants with
M3B1 treatment which had the highest number of fruits.

\section{CONCLUSION}

Based on the research that has been done, it can be concluded that:

1. Effective bioactivator composition used for making liquid organic fertilizer based on chicken manure, M3B5 with composting time of 21 days,

2. The effect of the composition of the bioactivator on the indicator of the $\mathrm{pH}$ value and the respective macro elements is the composition of B5 $(30 \mathrm{~mL}$ Biosca $+10 \mathrm{~mL} \mathrm{~T}$. harzianum) with a $\mathrm{pH}$ value: 7.1, N level: $5.33 \%$, P level: $2.41 \%$, K level: $1.34 \%$ at third weeks,

3 . The results of the analysis show that the composition of bioactivator is very influential on tomato plants on observation at tenth weeks, namely treatment of M3B5 with a value for growth of plant height: 197,7 cm, average plant diameter: $16,27 \mathrm{~mm}$, average leaf produced: 41 sheets, and for Production the average number of fruits: 32 pieces, average fruit weight: 32,4 grams.

\section{REFERENCES}

Amuwaraharja, I.P., 2006, Analysis of Waste Processing Technology with Analytical Hierarchy Process and Contingency Valuation Method, Thesis, Post Graduate, IPB, Bogor Campbell, N.A., Reece, J.B., \& Mitchell, L.G., 2012, Biology Volume 2, Eighth Edition, Interpreting: Damaring Tyas Wulandari, Erlangga Publisher, Jakarta 
Dobermann, A., Thomas F., 2000, Nutrient Disolders \& Nutrien Management, IRRI, Canada.

Eviati, S., Sulaeman, 2009, Technical Guidelines for Analysis of Soil Chemistry; Plants, Water, and Fertilizers, Soil Agriculture Center, Bogor.

Erona, Meisilva., 2016, Growth of Vanilla Seeds (Vanilla Planifolia) Inoculated with Arbuscular Mycorrhizal Fungi and Trichoderma harzianum in Ultisol Soil, Thesis, Post-Graduate IPB, Bogor

Fitria, Yulya, 2008, Manufacture of liquid organic fertilizer from fisheries industry wastewater using acetic acid and EM-4 (effective microorganism 4), Aquatic, 1 (2): 24-26

Gaur, D.C., 1980, Present Status Of Composting and Agricultural Aspect, in; Hesse, P.R. (ed), Improving Soil Fertility Through Organic Recycling, Compost Tecnology, FAO of United Nation, New Delhi

Hilda Chalimatus S.C., 2013, Effectiveness of Trichoderma harzianum and Microbial Dirt on Mushroom Composting in Sludge Waste, Final Project II, Semarang State University

Indriani, Y.H., 2004, Making Compost on a Flash, Penebar Swada, Jakarta.

Irsal, Las, 2006, Organic Fertilizer and Biofertilizer, Research and Development Center, Bogor.
Hadisuwito, S., 2008, Making Liquid Fertilizers, PT. Agromedia Pustaka, Jakarta.

Hartika, W., L.R. Widowati, 2006, Fertilizer, Litbang Hall, Bogor.

Lahuddin, 2007, Aspects of Macro Elements in Soil Fertility, Papers presented in the Inauguration of the Position of Professors in the Field of Soil Fertility in the Faculty of Agriculture, Student Center, North Sumatra, February 24

Marlinda, 2015, Effect of addition of EM4 and promi bioactivators in the manufacture of organic liquid fertilizer from household waste, Conversion, 4 (2): 1-2

Marsono, and Paulus, S., 2001. Root fertilizer: types and applications. Self-help spreader. Jakarta.

Maspary, 2011, Trichoderma Sp As a Biological and Biofungicide Fertilizer, http://www.gerbangpertanian.com /2011/02/trichoderma-sp-sebagaipupuk Biological.html (accessed January 1, 2016, 23.00).

Mulyadi, S, 1994, Fertilizers and Fertilizer Ways, Rineka Cipta, Jakarta

Norma, A.N., Mulyanti, Wulan, S. P., and M., Rafi, 2014, Determination of Iron Levels in Multivitamin Tablets Using Atomic and Uv-Vis Absorption Spectrophotometry, Instrumental Analysis Practicum Report, Department of Chemistry FMIPA IPB, Bogor

Nyoman, I.Y.S., Gede, W., Gede, M.A., 2012, Application of Types of Organic Fertilizers in Rice Plants 
in Organic Agriculture, Tropical Agroecotechnology, 1 (2): 10-105. Rilawati, Dyah, 2009, User Study of Biosca for Utilization of Leachate Water into Liquid Fertilizers, Thesis, Post-Graduate Programs, Universities Next to March, Surakarta

Ruhnayat, Agus, 2007, Determining the Basic Needs of N Nutrients, P, K for the Growth of Panili Plants (Vanilla Planifolia Andrews), Litro Bulletin, 18, (1), 49-59.

Rose, Shela A, 2011, Effectiveness of Trichoderma harzianum Rifai as a biofungicide against pathogenic fungi in Japanese taro tubers, Thesis, Biology Study Program FMIPA UNS, Semarang

Sinaga, D., 2009, Making Liquid Fertilizer from Organic Waste by Using Biosca as a Starter, Thesis, Dep. Tekpar FAPERTA USU, Medan.

Sitompul, S.D., 2015, Diagnosis of Plant Nutrition Deficiency, Modules, Faculty of Agriculture UB, Malang

Setoadji, Damar, 2016, It's fun to grow polybag \& tabulampot vegetables, Araska Publisher, Yogyakarta

Sundari, Elmi, Ellyta, S., and Riko, R., 2012, Making Liquid Organic Fertilizers Using Biosca and EM4 Bioactivators, Proceedings of SNTK, 1907 - 0500

Suriadikarta, D.A., Diah S., 2006, Organic Fertilizer Quality Standards, Research and Development Center, Bogor.

Sutanto, R., 2002, Application of Organic Farming and Community
Development, Kanisis, Yokyakarta.

Wahida, Nadira R.S., Hernursye H.L., 2011, Application of Chicken Cage Fertilizer in Three Sorghum Varieties. Thesis, Faculty of Agriculture, Hasanuddin University, Makassar

Widawati, S., Suliasih, A., and Muharram, 2010, Effect of Compost enriched Nitrogen and Phosphate Solubilizing Bacteria on Kapri Plant and Phosphatase in Soil, J. Hort, 20 (3): 210-2012.

Yulipriyanto, H., 2000, Composting of Thermophilic Phases of Chicken Organic Waste in Artificial Environments Using Indore Heap Method, Thesis, Biology Education Department FMIPA UNY, Yogyakarta. 